\title{
Pembuktian Paulus sebagai Penulis Surat Ibrani Berdasarkan Bukti Internal
}

Joy Sopater Wasiyono

Sekolah Tinggi Teologi Paulus Medan, Sumatera utara, Indonesia

joy.sopater@sttpaulusmedan.ac.id

\begin{abstract}
The Epistle to the Hebrews is an epistle that has sparked a lot of controversy. The most common debates are those relating to authorship. Among the issues of authorship, the most provocative of debate is the discussion about the author. The most important tool in the investigation of the author of a writing is the internal evidences of the writing itself. This research is focused on proving Paul as the author of Hebrews based on internal evidences. The research method used is descriptive qualitative non-experimental research with exegetic and biblical approaches to texts that are considered to have significance in the proof of the author to the Hebrews. After careful examination of the text of The Epistle to the Hebrew, is found 25 internal evidences for the author of the Hebrews. These internal evidences were subsequently used to prove Paul's authorship of the Hebrews.
\end{abstract}

Keywords: author of Hebrews; the apostle Paul; The epistle to the Hebrews

Abstrak: Surat Ibrani adalah surat yang memicu banyak kontroversi. Perdebatan paling umum adalah yang berhubungan dengan kepenulisannya. Di antara persoalan-persoalan kepenulisan, yang paling memicu perdebatan adalah pembahasan tentang siapa penulisnya. Alat bantu terpenting dalam penyelidikan penulis sebuah tulisan adalah bukti-bukti internal dari tulisan itu sendiri. Penelitian ini difokuskan untuk membuktikan Paulus sebagai penulis surat Ibrani berdasarkan bukti-bukti internal. Metode penelitian yang digunakan adalah penelitian kualitatif deskriptif non eksperimental dengan pendekatan eksegesis dan biblika terhadap teks-teks yang dianggap memiliki signifikansi dalam pembuktian penulis surat Ibrani. Setelah dilakukan penelitian yang cermat terhadap teks surat Ibrani, maka diperoleh 25 bukti internal penulis surat Ibrani. Bukti-bukti internal ini selanjutnya digunakan untuk membuktikan kepenulisan Paulus atas surat Ibrani.

Kata kunci: penulis surat Ibrani; rasul Paulus; surat Ibrani

\section{PENDAHULUAN}

Surat Ibrani adalah surat yang begitu misterius bila ditinjau dari sisi historis kepenulisannya. Misterinya telah memunculkan beragam penafsiran, kontroversi, dan perdebatan bahkan sejak zaman bapa-bapa gereja. Barclay mengutip tulisan E. F. Scott yang mengatakan: "Dalam banyak hal Surat Ibrani merupakan teka-teki dalam Perjanjian Baru."1 Perdebatan paling mendasar dan paling umum dari surat Ibrani adalah perdebatan yang berhubungan dengan kepenulisan surat Ibrani yakni siapa penulisnya, siapa penerimanya, di mana tempat penulisannya, kapan waktu penulisannya, dan apa bentuk sastranya. Di antara perso2006), 7.

${ }^{1}$ William Barclay, Pemahaman Alkitab Setiap Hari - Surat Ibrani (Jakarta: PT. BPK Gunung Mulia, 
alan-persoalan tersebut yang paling memicu perdebatan adalah pembahasan tentang siapa penulisnya.

Surat Ibrani sampai kepada pembaca sekarang secara anonim, namun penulisnya sangat dikenal oleh para penerimanya. Sejak abad pertama, orang-orang sudah berspekulasi mengenai kemungkinan pengarangnya. Ada banyak nama yang pernah diajukan oleh para sarjana gereja maupun pakar-pakar teologi Perjanjian Baru. Peneliti menemukan setidaknya ada 23 nama yang pernah diajukan oleh sarjana-sarjana gereja sepanjang zaman sebagai penulis surat Ibrani, yakni: 1) Apolos, 2) Akwila \& Priskila, 3) Filipus (diaken/penginjil), 4) Timotius, 5) Silas/Silwanus, 6) Aristion, 7) Kleopas, 8) Epafras, 9) Yohanes Zebedeus, 10) Yudas, 11) Markus, 12) Maria (ibu Yesus), 13) Petrus, 14) Stefanus, 15) Titus, 16) Zenas, 17) Pseudo-Paulus, 18) seorang Rahib Kristen, 19) Orang yang tidak dikenal, 20) Lukas, 21) Barnabas, 22) Klemens dari Roma, dan 23) Paulus. ${ }^{2}$ Origenes seperti dinyatakan oleh Eusebius, sekalipun mempunyai pendapat sendiri tentang siapa penulis surat Ibrani, tetapi juga berkata bahwa sesungguhnya hanya Allah yang tahu siapa penulis surat Ibrani. ${ }^{3}$ Itu sebabnya Marxsen berkata: 'Ibrani bagaikan Melkisedek (7:3), 'tanpa ayah, tanpa ibu, tanpa silsilah." ${ }^{\prime 4}$ Kendatipun tidak pernah ada kesepakatan akhir di kalangan sarjana gereja, penyelidikan penulis surat Ibrani tetap saja menarik.

Alat bantu terpenting dalam penyelidikan penulis sebuah tulisan adalah bukti-bukti internal dari tulisan itu sendiri. Hal ini sesuai dengan yang dikatakan Wahono, bahwa ada dua cara yang bisa ditempuh untuk menjawab pertanyaan-pertanyaan yang berhubungan dengan kepenulisan sebuah buku. Cara pertama adalah meneliti bukti-bukti di luar bukubuku yang bersangkutan, dan cara kedua adalah meneliti bukti-bukti serta keterangan yang ada di dalam buku yang bersangkutan. ${ }^{5}$ Cara yang pertama sering disebut sebagai penelitian "Bukti-bukti eksternal" dan cara kedua disebut penelitian "bukti-bukti internal." Penelitian ini difokuskan untuk menemukan bukti-bukti internal penulis surat Ibrani yang akan dapat digunakan sebagai alat pembuktian kepenulisan Paulus atas surat Ibrani.

\section{METODOLOGI}

Metode penelitian yang digunakan adalah penelitian kualitatif deskriptif non eksperimental dengan pendekatan eksegesis dan biblika terhadap teks-teks yang dianggap memiliki signifikansi dalam pembuktian penulis surat Ibrani. Melalui penelitian yang bersifat eske-

\footnotetext{
${ }^{2}$ Nama-nama kandidat tersebut secara kolektif disebutkan oleh 1) Raymond E. Brown, An Introduction to the New Testament, (New York: Doubleday, 1997), 695; 2) Paul Ellingworth, The Epistle to the Hebrews: A Commentary on the Greek Text, (Grand Rapids: Wm. B. Eerdmans Publishing, 1993), 3-21; 3) Donald Guthrie, New Testament Introduction 4th ed, (Leicester: Apollos; Downers Grove: Inter-Varsity, 1990), 671-682; 4) Philip Edgcumbe Hughes, A Commentary on the Epistle to the Hebrews, Grand Rapids: Eerdmans, 1977), 355-356; 5) Richard C. H. Lenski, Commentary on the New Testament: The Interpretation of the Epistle to the Hebrews and of the Epistle of James, (Peabody: Hendrickson, 1966) 14; 6) J. Vernon McGee, "The Epistle to the Hebrews" Thru the Bible with Vernon McGee, Vol. 5, (Nashville: Nelson, 1983), 619-620; 7) Robert W. Ross, The Wycliffe Bible Commentary-Ibrani, Volume 3, (Malang: Penerbit Gandum Mas, 2008), hal. 920; 8) F. F. Bruce, The Epistle to the Hebrews - Revised Edition, (Michigan: William B. Eerdmans Publising Company, 1990), 14-20; 9) David Lewis Allen, Lukan Authorship of Hebrews, (Nashville, Tennessee: B\&H Publishing Group, 2010), 13.

${ }^{3}$ Eusebius Pamphilus, Historia Ecclesiae, 6.25.6.

${ }^{4}$ Willi Marxsen, Pengantar Perjanjian Baru - Pendekatan Kritis Terhadap Masalah-masalahnya, (Jakarta: PT BPK Gunung Mulia, 2014), 272.

${ }^{5}$ S. Wismoady Wahono, Di Sini Kutemukan, (Jakarta: PT. BPK Gunung Mulia, 2009), 30.
} 
getikal dan biblikal ditemukan bukti-bukti internal penulis surat Ibrani yang selanjutnya akan digunakan untuk membuktikan kepenulisan Paulus atas surat Ibrani.

\section{HASIL DAN PEMBAHASAN}

\section{Bukti-bukti Internal Surat Ibrani}

Penulis Ibrani sangat sedikit menceritakan tentang dirinya. Namun berdasarkan penelitian eksegesis dan biblical terhadap teks Ibrani, berikut dipaparkan lima kategori petunjuk penulis surat Ibrani, yang meliputi: 1) Ciri fisik penulis, 2) Latar belakang pendidikan penulis, 3) Latar belakang keluarga penulis, 4) Kehidupan rohani dan pelayanan penulis, 5) Informasi lain.

\section{Ciri Fisik Penulis}

Pertama, penulis adalah seorang laki-laki

- Pemakaian kata ganti 'aku' untuk mengacu pada diri sendiri dalam 11:32.

KJV : "for the time would fail me to tell of ..."

TB LAI : "apabila aku hendak menceriterakan tentang ..."

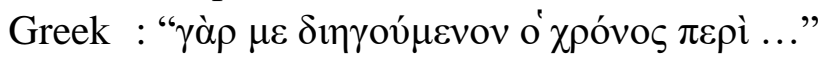

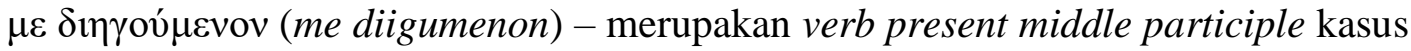
accusative singular masculine.

- Penggunaan kata ganti 'kami' dalam 5:11

KJV : "Of whom we have many things to say ..."

TB LAI : "Tentang hal itu banyak yang harus kami katakan ..."

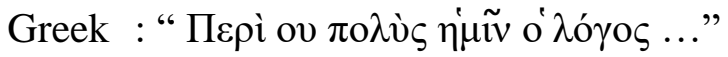

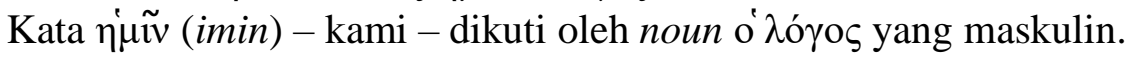

Hal-hal tersebut merupakan bukti internal bahwa penulisnya adalah seorang laki-laki.

Kedua, penulis setidaknya berusia 50 tahun saat surat Ibrani ditulis. Jika surat Ibrani ditulis sekitar tahun 64M, maka ada beberapa petunjuk bahwa penulisnya pada waktu itu setidaknya berumur 50 tahun.

- Penulis adalah seorang guru/ pengajar senior (5:12). Dalam tradisi Yahudi, seorang baru boleh menjadi pengajar pada umur 30 tahun. Itu sebabnya Yesus baru tampil setelah ia berumur 30 tahun. Untuk menjadi pengajar senior, seseorang harus sudah mengajar selama setidaknya 10-20 tahun.

- Penulis adalah seorang Kristen yang dewasa, itu sebabnya ia meminta agar pembaca suratnya menjadi dewasa $(5: 12-14)$.

- Penulis adalah seorang pria yang usianya cukup tua. Dalam penutupnya, ia memerintahkan sesuatu $(13: 1-5)$ dan menasihati pembaca suratnya $(13: 19,22)$. Ini bukan tindakan yang lumrah dilakukan oleh seorang yang muda.

- Semua penulis PB rata-rata berusia 50 tahun atau lebih pada tahun 64M.

\section{Latar Belakang Pendidikan Penulis}

Pertama, penulis adalah seorang yang terpelajar

- Penulis menguasai berbagai aspek dalam kitab Musa (pasal 7-10)

- Penulis menguasai PL. Dalam suratnya ia mengutip setidaknya 20 kitab PL: Kejadian (4:4, 10: 6:8, 14, 7:1-2; 11:3-29; 12:16-17, 24; 13;2), Keluaran (5:4; 8:5; 9:2-5, 19-20; 10:11, 29; 12:18-20), Imamat (5:3; 6:19; 7:27; 9:7, 13, 21-22; 13:11), Bilangan (3:2, 16-18; 7:5; 9:6), Ulangan $(4: 8 ; 10: 28,30 ; 12: 18-19 ; 12: 21,29 ; 13: 5)$, Yosua (11:30-31; 13:5), Hakim-hakim 11:32, 2 Samuel 1:5, 1 Raja-raja 11:35-36, 1 Tawarikh 1:5, 2 Tawarikh 11:37, Ayub 12:5-6, Mazmur (1:5-13; 2:6-8; 12; 3:7-11, 
$15 ; 4: 3,5,7 ; 5: 5-6 ; 6: 20 ; 7: 17,21 ; 8: 1 ; 10: 5-7,12-13 ; 13: 6)$, Amsal 12:5-6, Yesaya $(2: 13 ; 9: 28 ; 10: 27 ; 12: 12)$, Yeremia $(8: 8-12 ; 10: 16-17 ; 11: 36)$, Yehezkiel 10:22, Daniel 11:34, Habakuk 10:37-38, Hagai 12:26.

- Penulis menguasai sejarah Israel. Ia menyebut Musa (ps. 3; 7:14; 8:5; 9:19; 10:28; 11:23-24; 12:21), Daud (4:7; 11:32), Yosua (4:8), Harun $(5: 4 ; 7: 11 ; 9: 4)$, Melkisedek (5:6, 10; 6:20; ps. 7), Abraham (6:13, 15; ps. 7; ps. 11), Lewi (ps. 7), Habel, Kain, Henokh, Nuh, Sara, Ishak, Yakub, Esau, Yusuf, Rahab, Gideon, Barak, Simson, Yefta, Samuel (pasal 11)

- Penulis menguasai kebiasaan retoris dan sastra dari zaman Helenistik. Ia kelihatannya mengenal gagasan yang beredar secara umum di kalangan pemikir Yunani. Cara bagaimana ia mempertentangkan dunia surgawi dan dunia materi (pasal 1, 2, dan 9), juga ada dalam konsepsi Plato. ${ }^{6}$

- Banyak pakar menyimpulkan bahwa penulis menguasai berbagai disiplin ilmu meliputi komposisi, literatur, sejarah, orasi dan retorika, hermeneutika, filosofi, hukum, dan tentu saja teologi. ${ }^{7}$

Kedua, penulis bisa berkomunikasi dalam beberapa bahasa

- Penulis menguasai bahasa Ibrani dan bahasa Ibrani Masoret. Terbukti dari interpretasinya terhadap PL. ${ }^{8}$ Misalnya dalam 7:1-2 penulis menafsir Melkisedek sebagai raja kebenaran dan damai sejahtera. Ini merupakan interpretasi arti dari istilah tersebut dalam bahasa Ibrani (Kej. 14:18).

- Penulis menguasai bahasa Yunani dan mengutip dari terjemahan Yunani PL yang disebut Septuaginta. ${ }^{9}$ Ia menulis dengan menggunakan tata bahasa dan sintaksis bahasa Yunani klasik. ${ }^{10}$ Surat Ibrani juga ditulis dalam bahasa Yunani yang sangat baik, ${ }^{11}$ bahkan mempunyai gaya bahasa Yunani yang terbaik di seluruh PB. ${ }^{12}$ Eusebius, mengatakan bahwa surat ini ditulis dengan bahasa Yunani yang lebih baik, akan diakui oleh semua orang yang mampu melihat perbedaan gaya bahasa. ${ }^{13}$

- Penulis juga mungkin menguasai bahasa Latin. Dalam 13:24, penulis mengenal beberapa orang Kristen Italia. Pada waktu itu, Roma menguasai dunia Mediterania. Menurut Barclay, pejabat, tentara, dan masyarakat sipil Roma tinggal di setiap provinsi di bawah kekaisaran Roma. Semua pejabat Roma tersebut diperintahkan untuk berbicara dan menulis dalam bahasa Latin, berpakaian model Latin, dan memakai nama Latin. ${ }^{14}$ Itu sebabnya ada kemungkinan bahwa penulis Ibrani juga bisa bahasa Latin.

Jadi penulis menguasai bahasa Ibrani, Yunani, dan mungkin juga Latin.

Ketiga, penulis berasal dari luar wilayah Israel/Palestina

\footnotetext{
${ }^{6}$ John Drane, Memahami Perjanjian Baru - Pengantar Historis - Teologi (Jakarta: PT. BPK Gunung Mulia, 2013), 478.

${ }^{7}$ Pakar-pakar tersebut disebutkan dalam karya Richard A. Thiele, A Reexamination of the Authorship of the "Epistle to the Hebrews", (Milwaukee, USA: University of Wisconsin - ProQuest Dissertations Publishing, 2008), 79-92.

${ }^{8}$ Richard A. Thiele, Op. Cit., 92-94.

${ }^{9}$ J. Wesley Adam, Alkitab Penuntun Hidup Berkelimpahan, (Malang: Penerbit Gandum Mas \& Jakarta: LAI, 2006), 2052.

${ }^{10}$ Bob Utley, Keunggulan Perjanjian Baru: Ibrani - Kumpulan Komentari Panduan Belajar Perjanjian Baru, Vol. 10, (Texas: Bible Lesson International, 1999), 2.

${ }^{11}$ William Barclay, Pemahaman Alkitab Setiap Hari - Surat Ibra, 12.

${ }^{12}$ Drane, Memahami Perjanjian Baru - Pengantar Historis - Teologi, 477.

${ }^{13}$ Eusebius, Historia Ecclesiae, 6.25.

${ }^{14}$ William Barclay, Pemahaman Alkitab Setiap Hari-Surat Filipi, Kolose, 1 dan 2 Tesalonika, (Jakarta: PT. BPK Gunung Mulia, 2004), 51.
} 
- Ada beberapa bukti dalam surat Ibrani bahwa penulis Ibrani adalah seorang yang berasal dari luar wilayah Israel/Palestina. Salah satu buktinya adalah bahwa penulis memiliki gaya sastra sangat baik. ${ }^{15}$ Kefasihan Yunani penulis menunjukkan bahwa dia belajar bahasa di luar Palestina, di mana orang biasanya berbicara Yunani, karena di Palestina, bahasa sehari-harinya adalah bahasa Aram. Penguasaan Yunani lanjut menunjukkan bahwa ia sudah belajar bahasa Yunani ketika ia masih kecil.

- Gaya berpikir, cara mengembangkan teologinya, serta keterampilannya dalam menafsir PL membuat beberapa penafsir berkesimpulan bahwa penulisnya adalah seorang Kristen berlatar belakang Yahudi diaspora. ${ }^{16}$

- Bukti lain adalah bahwa penulis juga bergaul dengan orang-orang non Yahudi. Dia menyebutkan Timotius yang ayahnya adalah orang Yunani (Kis. 16:1-3) dan beberapa orang Italia (13:23-24). Orang Yahudi Palestina, termasuk mereka yang mengaku diri sebagai orang Kristen, tidak bergaul dengan bangsa-bangsa lain, supaya mereka tidak menjadi najis (Kis. 11:3-4; Gal. 2:11-13).

Keempat, penulis pernah menimba ilmu di kota besar. Penulis Ibrani suka membaca, ia pembaca yang baik. Kedalaman pengetahuannya tentang literatur adalah bukti bahwa dia telah membaca sejumlah besar buku. Hal ini juga menunjukkan bahwa ia memiliki akses ke perpustakaan yang baik selama tahun-tahun belajarnya. Perpustakaan umum dan swasta bisa ditemukan di banyak provinsi Kekaisaran Romawi. ${ }^{17}$ Selain itu, sudah dibahas bahwa penulis Ibrani adalah seorang yang berpendidikan. Tulisannya bergaya sastra formal mendekati Yunani Klasik. ${ }^{18}$ Dia menunjukkan kompetensi dalam retorika, filsafat, dan hukum Yahudi. Hal ini membuktikan bahwa ia memiliki sekolah lanjutan pada bidangbidang tersebut. Sekolah-sekolah tinggi tersebut terletak di seluruh wilayah Mediterania, terutama di kota-kota di mana guru dapat menarik lebih banyak siswa, dan dengan demikian mendapatkan penghasilan yang lebih banyak. Hal ini menunjukkan bahwa penulis pernah menimba ilmu di kota besar.

Kelima, penulis pernah belajar dari guru yang berkualitas. Para sarjana menganggap bahwa surat Ibrani adalah sebuah karya sastra yang unggul. Attridge menggambarkannya sebagai "produk seni retorika." 19 Brown menulis, "Dinilai dari semua standar, surat Ibrani adalah salah satu tulisan yang paling mengesankan di PB." ${ }^{20}$ Lindars menyatakan, "Bahasa Yunani dan gaya Ibrani adalah yang terbaik dalam PB." ${ }^{21}$ Keunggulan sastra Ibrani menunjukkan bahwa, ketika penulis masih seorang pelajar, ia memiliki guru yang sangat baik.

\section{Latar Belakang Keluarga Penulis}

Pertama, penulis adalah keturunan Yahudi. Penulis mengidentifikasikan dirinya dengan orang-orang Yahudi. 1:1-2 ia menyebut "nenek moyang kita" dan "berbicara kepada kita". Berdasarkan konteks keseluruhan surat Ibrani, "nenek moyang kita" yang dimaksud adalah

\footnotetext{
${ }^{15}$ William Barclay, Pemahaman Alkitab Setiap Hari-Surat Ibrani, 12.

${ }^{16}$ Samuel Benyamin Hakh, Perjanjian Baru - Sejarah, Pengantar, dan Pokok-pokok Teologinya, (Bandung: Bina Media Informasi, 2010), 256.

${ }^{17}$ Thiele, Op. Cit, 98.

${ }^{18}$ Samuel A. Cartledge, A Conservative Introduction to the New Testament. 2nd ed, (Grand Rapids: Zondervan, 1938), 150.

${ }^{19}$ Harold W. Attridge, The Epistle to the Hebrews: A Commentary on the Epistle to the Hebrews. Ed. Helmut Koester, (Philadelphia: Fortress, 1989), 14.

${ }^{20}$ Raymond E. Brown, An Introduction to the New Testament, (New York: Doubleday, 1997), 683.

${ }^{21}$ Barnabas Lindars, The Theology of The Letter to The Hebrews, (Cambridge: Cambridge University Press, 1991), 21.
} 
leluhur orang-orang Yahudi dimulai dari Abraham yang nama-namanya juga ia sebutkan dalam pasal 11. Penulis memiliki pengetahuan yang mendalam tentang Yudaisme. Ia menguasai hukum-hukum ibadah dalam kitab Musa (pasal 7-10). Ketika penulis memperkenalkan kutipan dari PL, ia menggunakan kalimat panjang untuk menghindari menyebutkan nama Allah yang kudus. Praktek ini adalah ciri khas agama Yahudi dan sastra rabinik. Beberapa contohnya, dalam teks KJV misalnya: "he saith" (1:6), "but one in a certain place testified, saying" (2:6), "for he spake in a certain place" (4:4), "saying in David" (Ibr. $4.7 \mathrm{KJV})$, dll. Penulis tahu dan menggunakan bahasa Ibrani terbukti dari interpretasinya terhadap teks-teks PL yang dikutip dalam surat ini. Hal-hal di atas adalah bukti penulis surat Ibrani adalah keturunan Yahudi.

Kedua, penulis berasal dari keluarga yang mapan. Dunia Yunani dan Romawi kuno tidak menganut sistem modern wajib belajar yang didukung oleh negara seperti zaman sekarang. Tidak ada sekolah umum yang gratis di zaman itu. ${ }^{22}$ Sebaliknya, orang tua menyewa guru pribadi atau tutor, dan membayar mereka untuk mengajar anak-anak mereka. Menurut Tenney, di beberapa keluarga Romawi, seorang budak biasanya ditugaskan untuk memberikan pendidikan awal kepada anak-anak hinggai anak itu dinyatakan sebagai seorang pemuda dengan kewajiban-kewajiban orang dewasa. Selanjutnya anak-anak muda yang kaya akan pergi ke luar untuk melanjutkan pendidikannya di perguruan tinggi di Atena, Rodos, Tarsus, Aleksandria, atau menghadiri kuliah para filosof keliling. ${ }^{23}$ Euenos dari Paros (abad $5 \mathrm{sM}$ ), yang hidup sezaman dengan Socrates, harus membayar biaya kuliah sebesar lima minas, atau lima ratus dirham. ${ }^{24}$ Isokrates (sekitar 385-322 sM), seorang orator Athena, dikenakan biaya kuliah sepuluh minas, atau seribu dirham (Plutarch 693). ${ }^{25}$ Protagoras (490-420 sM), seorang filsuf Thrakian, mungkin dibebankan sampai seratus minas, atau sepuluh ribu dirham. ${ }^{26}$ Keluarga kelas bawah tidak memiliki kemampuan keuangan untuk membayar biaya tinggi seperti. keluarga kelas menengah juga tidak mampu untuk membiayai dengan baik, kecuali mereka melakukan pengorbanan yang besar. Hanya keluarga kelas atas yang bisa memenuhi biaya kuliah tersebut. Berdasarkan informasi latar belakang ini, fakta bahwa penulis Ibrani menunjukkan keterampilan retorika yang sangat baik adalah bukti bahwa ia berasal dari keluarga yang kaya.

\section{Kehidupan Rohani dan Pelayanan Penulis}

Pertama, penulis memiliki banyak kesamaan kepercayaan dengan mazhab Farisi. Di zaman PB, ada beberapa sekte/mazhab orang Yahudi, seperti Saduki, Essenes, dan Farisi. Orangorang Farisi percaya kepada kebangkitan, malaikat, makhluk roh, immoralitas jiwa/roh manusia, pengadilan ilahi, ganjaran setelah kematian, dan mengakui baik kitab Musa maupun tulisan para nabi (39 kitab PL). Sekte Saduki sama sekali tidak percaya kepada hal-hal tersebut dan hanya berpegang kepada lima kitab Musa. Sekte Esen sangat

\footnotetext{
${ }^{22}$ Merrill C. Tenney, Survei Perjanjian Baru, (Malang: Penerbit Gandum Mas, 2009), 70.

${ }^{23}$ Ibid, 70-71.

${ }^{24}$ Plato, The Apology of Socrates - Selections from Plato with Introduction and Notes. Ed. Lewis Learning Forman, (London: Macmillan, 1939), 20 b.

${ }^{25}$ Plutarch, Demosthenes - The Lives of the Noble Grecians and Romans - Great Books of the Western World - Ed. Robert Maynard Hutchins, Vol.14, (Chicago: Britannica, 1952), 693

${ }^{26}$ Rose Gilbert, Plato's Apology: Commentary, Bryn Mawr: Thomas Library, (Bryn Mawr College, 1989), 11
} 
menghormati Musa, memiliki imam dunia, hidup selibat. Penulis Ibrani adalah seorang yang:

- Percaya kepada adanya kebangkitan setelah kematian $(6.2 ; 11.19,35 ; 13: 20)$.

- Percaya akan keberadaan malaikat-malaikat $(1: 4-7,13 ; 2: 2,5,7,9,16 ; 12: 22$; 13:2).

- Percaya akan keberadaan makhluk roh lainnya $(1: 7,14 ; 2: 4 ; 3: 7 ; 4: 12 ; 6: 4 ; 9: 8,14$; $10: 15,29 ; 11: 27 ; 12: 9,23)$.

- Percaya kepada immoralitas jiwa/roh manusia (11:5; 12:23).

- Percaya akan adanya penghakiman $(9: 27 ; 10: 27,30 ; 12: 23)$.

- Percaya akan adanya ganjaran setelah kematian $(2: 2-3 ; 6: 2 ; 9: 27 ; 10: 27-31 ; 12: 29)$.

- Percaya kepada seluruh PL, dibuktikan dengan kutipan terhadap setidaknya 20 kitab PL dalam surat Ibrani.

- Tapi berbeda dengan Farisi, ia menyatakan bahwa hukum Taurat tidak efektif (6:1; 7, 11-12, 16, 18-19, 28; 10:1). Sebaliknya, dia menganjurkan anugerah Allah (2:9;. $4: 16 ; 10: 29 ; 12: 15,28 ; 13: 9,25)$.

- Menghormati Yesus jauh lebih tinggi dari Musa (3:1-6).

- Lebih menekankan imam surgawi (Yesus) ketimbang imam dunia (Harun) (4:145:10; 7:11-28).

- Tidak seperti orang Essenik yang memilih hidup selibat, penulis Ibrani mendorong pembacanya untuk menjaga kekudusan pernikahan (13:4).

Semua fakta di atas menunjukkan bahwa penulis memiliki lebih banyak kepercayaan yang sama dengan orang Farisi ketimbang orang Saduki.

Kedua, Penulis adalah seorang Kristen.

- Penulis percaya kepada Allah TriTunggal, Bapa (1:1-2, 5; 12:9), Anak (1:2, 5, 8; 4:14; 5:5, 8; 6:6; 7:28; 10:29), dan Roh Kudus (2:4; 3:7; 6:4; 9:8; 10:15).

- Penulis percaya bahwa Yesus adalah Kristus $(3: 1,6,14 ; 5: 5 ; 6: 1 ; 9: 11,14,24,28$; $10: 10 ; 11: 26 ; 13: 8,21)$, Tuhan $(2: 3 ; 7: 14 ; 13: 20)$, disalibkan $(6: 6 ; 12: 2)$, mati $(2: 9$, $14 ; 5: 7 ; 9: 15 ; 13: 20)$, bangkit dari kematian $(4: 14 ; 13: 20)$, naik ke Sorga $(4: 14$; $6: 20 ; 9: 11,24)$, duduk di sebelah kanan Allah $(1: 3 ; 8: 1 ; 10: 12 ; 12: 2)$, satu ketika akan datang kembali $(9: 28)$, untuk menghakimi manusia $(6: 2 ; 9: 27 ; 10: 26-31$; $12: 23,29 ; 13: 4)$.

- Penulis percaya kepada perjanjian baru $(7: 22 ; 8: 6 ; 12: 24)$, pengampunan dosa (8:12;. 9:14, 22; 10:17-18), baptisan orang percaya (6:2.); dan persekutuan orangorang kudus (gereja) $(10: 25 ; .12: 23 ; 13: 7,17,24)$.

Semua pernyataan di atas merupakan hal-hal umum dalam pengakuan iman Kristen. Maka jelas bahwa penulis Ibrani adalah seorang Kristen.

Ketiga, penulis meninggalkan Yudaisme dan mengikut Yesus. Pada bagian sebelumnya sudah dibuktikan bahwa penulis mewarisi Yudaisme. Tapi yang jadi pertanyaan adalah apakah dia lahir dalam keluarga Kristen dan dibesarkan sebagai seorang Kristen, atau dia tumbuh sebagai seorang Yahudi, dan kemudian beralih dari Yudaisme ke Kristen.

- Salah satu petunjuk bahwa penulis adalah seorang yang berpindah dari agama Yahudi ke Kristen adalah pengetahuan yang mendalam tentang Yudaisme. Jika ia dibesarkan dalam keluarga Kristen, ia tidak akan belajar banyak tentang agama Yahudi.

- Petunjuk lain bahwa penulis adalah seorang petobat adalah bahwa ia menggambarkan ketaatan hukum Yahudi sebagai "dead works" (6:1 KJV), "peraturan manusia" (7:16), "hukum yang dibatalkan dan tidak berguna" (7:18), tidak membawa kesempurnaan (7:19), merupakan bayangan dari hal-hal baik yang 
akan datang, dan bukan hakekat yang sebenarnya (10:1). Wawasan ini berasal dari refleksi penulis terhadap kasih karunia Allah.

Hal-hal tersebut menunjukkan bahwa ia adalah seorang yang beralih dari Yudaisme menjadi pengikut Yesus.

Keempat, penulis tidak pernah melihat langsung hidup dan pelayanan Yesus. Kehidupan dan pelayanan yang dimaksud adalah mulai dari baptisan Yohanes sampai pada hari Yesus terangkat ke sorga (Kis. 1:22). Ibrani 2:3-4 mengindikasikan bahwa penulis bukan saksi mata langsung kehidupan dan pelayanan Yesus, tetapi ia memang telah mendengar kesaksian tentang hidup dan pelayanan Yesus dari sejumlah saksi mata langsung.

Kelima, penulis termasuk golongan pemimpin gereja yang terpandang. Ibrani 13:7, 17, 24 menunjukkan bahwa penulis surat Ibrani adalah seorang pemimpin yang terpandang di tengah-tengah gereja.

- Penulis Ibrani adalah seorang yang memiliki wibawa dan otoritas di hadapan para pembaca suratnya. Itu sebabnya dalam suratnya, ia tidak ragu untuk memperingatkan mereka $(2: 1-3 ; .3: 12 ; 4: 1,11,13 ; 6: 4-6 ; 10: 26-31 ; 12: 3,15-17$, $25 ; 13: 4)$, mengajar mereka $(5: 12)$, memerintahkan sesuatu kepada mereka (3.1, $8,12-13 ; .7: 4 ; 10: 32,35 ; 12: 3,12-14,25,13: 1-3,5,7,9,17-18,22-24)$, mendesak mereka $(4: 1,11,14,16 ; .6: 1 ; 10: 22-24 ; 12: 1,28 ; 13: 13,15,22)$, dan menegur mereka $(5: 11-12 ; .10: 25-31 ; 12: 4-5)$.

- Penulis memiliki otoritas meskipun ia menulis dari lokasi yang berbeda (13.19, 23), dan meskipun para pembacanya memiliki pemimpin sendiri ditunjuk (13:7, 17, 24).

- Pada pertengahan abad pertama, pada dasarnya ada empat jenis pemimpin di

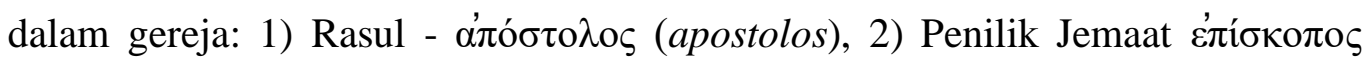

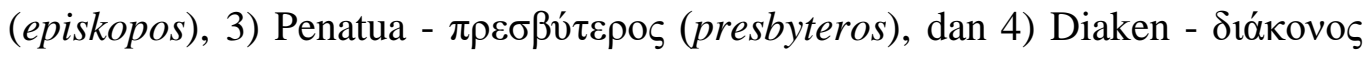
(diakonos). Di antara ke empat jenis pemimpin tersebut, termasuk ke manakah penulis Ibrani?

- Penulis kemungkinan besar bukanlah seorang diaken. Diaken ditunjuk untuk melayani sebuah gereja lokal tertentu. Mereka tidak memiliki wewenang apapun di gereja lainnya. Selain itu, mereka bertugas dalam pelayanan praktis, seperti membagikan makanan dan sedekah kepada orang miskin, agar pemimpin lain bisa menyerahkan diri penuh waktu untuk berdoa dan pelayanan Firman Allah (Kis. 6:2, 4). Penulis kemungkinan besar juga bukanlah seorang penatua. Penatua, sama seperti diaken ditahbiskan untuk mengawasi satu gereja saja. Mereka biasanya memberikan penyegaran rohani bagi kawanan itu saja (Kis. 20:28; 1Tim. 5:17-18; 1Pet. 5:1-2). Jika seorang penatua melakukan perjalanan keliling dengan mengunjungi gereja-gereja lain, dan menulis surat panjang untuk mereka, ia pasti akan mengabaikan kewajiban yang ditugaskan kepadanya.

- Penulis kemungkinan besar juga bukanlah penilik jemaat. Seorang penilik biasanya hanya mengelola urusan yang dimiliki oleh wilayahnya sendiri. Penulis bukanlah saudara Yesus. Berbeda dengan penulis Ibrani, yang berkeliling dari satu tempat ke tempat lain, saudara Yesus menetap secara permanen di Palestina. 
Itu sebabnya, hampir pasti bahwa penulisnya adalah seorang rasul. Lagi pula kitab-kitab dalam kanon PB haruslah berhubungan dengan seorang rasul.

Keenam, penulis adalah penginjil/ pengajar keliling. Beberapa ayat dalam pasal terakhir surat Ibrani mengindikasikan bahwa penulisnya adalah seorang guru dan pengkhotbah keliling yang berkeliling dari satu tempat ke tempat yang lain, dan mungkin perjalanannya agak jauh sehingga untuk sementara waktu ia harus absen.

- Ibrani 13:19: "Dan secara khusus aku menasihatkan kamu, agar kamu melakukannya, supaya aku lebih lekas dikembalikan kepada kamu."

- Ibrani 13:22: "Dan aku menasihatkan kamu, saudara-saudara, supaya kata-kata nasihat ini kamu sambut dengan rela hati, sekalipun pendek saja suratku ini kepada kamu.

- Ibrani 13:23: "Ketahuilah, bahwa Timotius, saudara kita, telah berangkat. Segera sesudah ia datang, aku akan mengunjungi kamu bersama-sama dengan dia."

Ketujuh, penulis adalah seorang penulis. Ibrani 13:22 menunjukkan bahwa ia memang adalah seorang penulis, dan jika dibandingkan dengan data-data sebelumnya, bahwa surat Ibrani merupakan surat dengan bahasa Yunani terbaik di PB, ditambah lagi dengan kedalaman tulisannya, maka tidak diragukan lagi bahwa ia adalah seorang penulis.

Kedelapan, penulis berafiliasi dalam sebuah komunitas penginjilan. Penulis bukanlah penginjil tunggal. Sebaliknya, ia terkait dengan orang-orang yang takut akan Allah di berbagai tempat. Masyarakat ini terdiri dari para penulis, juru tulis, kurir surat ini, beberapa pekerja injil lainnya. Ia tinggal, bekerja, dan bepergian dengan mereka. Itu sebabnya dalam 13:18, penulis menyebut ia dan teman-temannya itu sebagai "kami". Timotius juga tergabung dalam masyarakat penginjilan ini (13:23), termasuk juga saudarasaudara dari Italia (13:24). Ini adalah beberapa bukti yang menunjukkan bahwa penulis berafiliasi dalam sebuah komunitas penginjilan.

Kesembilan, penulis telah mengalami banyak sengsara dalam pelayanannya. Memang dalam suratnya ini, tidak ada pernyataan penulis tentang penderitaan yang dialaminya. Namun ada beberapa petunjuk yang bisa menunjukkan bahwa sang penulis sendiri adalah orang yang mengalami banyak penderitaan karena Kristus.

- Penulis mengajak pembacanya untuk mengingat kembali penderitaan mereka karena kepercayaan kepada Yesus (10:32-35).

- Penulis beberapa kali mengingatkan jemaat kepada Yesus yang menderita (2:9-10, $18 ; 5: 8 ; 9: 26 ; 13: 12$ ).

- Penulis juga mengingatkan mereka kepada penderitaan pahlawan-pahlawan iman dari PL (11:25, 34-38).

Penulis tidak akan memakai pengalaman penderitaan Kristus, jemaat, dan para pahlawan iman PL untuk menguatkan pembacanya, jika ia sendiri tidak mengalami banyak penderitaan dalam pelayanannya kepada Yesus Kristus.

Kesepuluh, penulis pernah mengalami realitas surgawi selama hidupnya. Penulis beberapa kali berbicara tentang realitas atau keadaan di surga dalam suratnya ini. Gambaran yang diberikannya tampaknya mengindikasikan bahwa ia pernah dibawa oleh Allah atau setidaknya menerima penglihatan tentang suasana/ realitas surga.

- Penulis menyebut tentang tingkat-tingkat surga (7:26).

- Penulis menyebutkan tentang benda-benda surgawi (9:23). 
- Penulis menceritakan bagaimana Kristus membawa darahnya ke surga sebagai persembahan (9:11-28).

- Penulis bahkan mendaftarkan hal-hal yang ada di surga: beribu-ribu malaikat, suatu kumpulan yang meriah; jemaat anak-anak sulung, yang namanya terdaftar di surga; Allah, yang menghakimi semua orang; roh-roh orang-orang benar yang telah disempurnakan; Yesus, Pengantara perjanjian baru; dan darah pemercikan, yang berbicara lebih kuat daripada darah Habel (9:22-24)

Melihat sedemikian jelasnya penulis mendaftarkan hal-hal yang ada di surga, maka adalah sangat mungkin bahwa ia pernah melihat realitas surga.

\section{Informasi Lain}

\section{Penulis mengenal Timotius}

Dalam Ibrani 13:23, penulis menyebutkan seorang pria yang bernama Timotius. Kelihatannya dia adalah orang yang sama yang disebutkan dalam Kisah Para Rasul dan sepuluh surat Paulus lainnya (Kis. 16:1; 17:14-15; 18:5; 19:22; 20:4; Rm. 16:21; 1Kor. 4:17; 16.10; 2Kor. 1:1, 19; Flp. 1:1; 2:19; Kol. 1:1; 1Tes. 1:1; 3:2, 6; 2Tes. 1:1; 1Tim. 1:2, 18; 6:20; 2Tim. 1:2; Flm. 1). Pernyataan penulis tentang Timotius mengungkapkan beberapa informasi:

- Penulis telah menerima berita dari utusan yang dikirim Timotius

- Penulis memberi tahu orang percaya lainnya tentang pembebasan Timotius: "Tahukah kamu, bahwa saudara kita Timotius sudah dibebaskan" (13:23 - KJV).

- Penulis menyebut Timotius sebagai "saudara kita Timotius."

- Penulis berencana untuk bepergian dengan Timotius dan mengunjungi pembaca.

- Ini adalah potongan-potongan bukti bahwa penulis mengenal Timotius.

\section{Penulis memiliki ketertarikan kepada tenda}

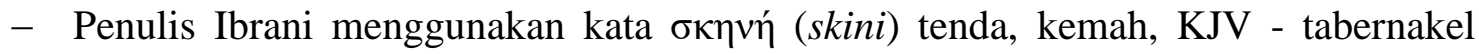
sebanyak sepuluh kali $(8: 2,5 ; .9: 2,3,6,8,11,21 ; 11: 9 ; 13: 10)$. Kata tersebut memiliki lima konotasi yang berbeda: 1) Tabernakel surgawi $(8: 2 ; .9: 11,24) ; 2)$ Tabernakel Musa (8:5;. 9:2, 3, 6, 8, 21; 13:10); 3) Tabernakel Herodes (13:10); 4) Tubuh Yesus (10:20); 5) Kemah Abraham, Ishak, dan Yakub selama mereka hidup $(11: 9)$

- Bukan sekedar menyebutkan, Penulis juga membahas tabernakel Musa dan sistem persembahan yang dilakukan di dalamnya dengan sangat akurat. Ritual Bait Suci pada waktu itu justru tidak dibahas mendalam (ps. 9-10).

- Penulis juga menunjukkan bahwa tabernakel surgawi adalah tabernakel sejati, buatan Tuhan dan bukan manusia (8:2), lebih besar dan sempurna dari tabernakel di bumi (9.11)

Jelaslah bahwa penulis memiliki minat terhadap tenda/ kemah.

\section{Penulis menggunakan banyak istilah hukum}

Dalam suratnya ini Penulis menggunakan banyak istilah teknis yang berhubungan dengan dunia hukum seperti:

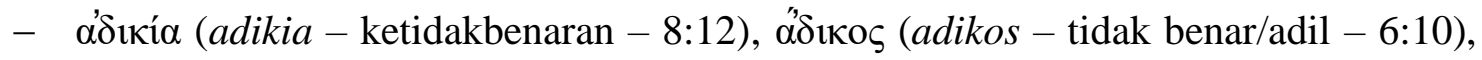

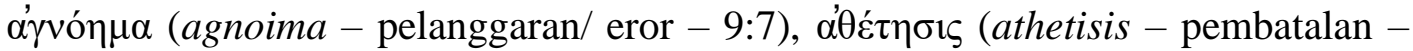

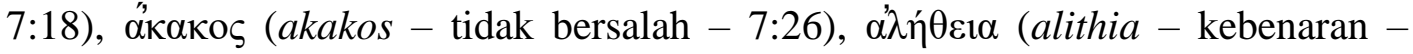

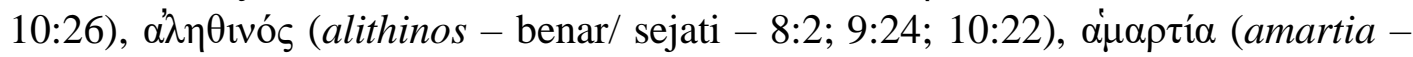
dosa - 1:3; 2:17; 3:13; 4:15; 5:1, 3; 7:27; 8:12; 9:26, 28; 10:2-4, 6, 8, 11-12, 17-18,

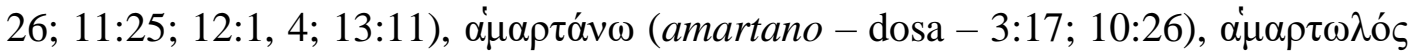


(amartolos - pendosa - 7:26), ávouía (anomia - tanpa hukum - 1:9; 8:12; 10:17),

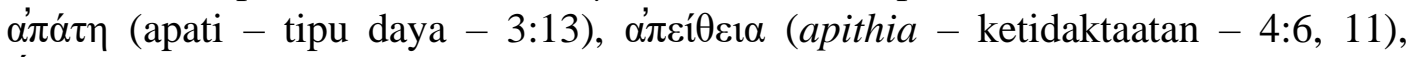

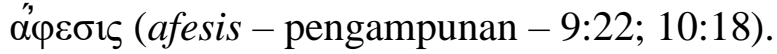

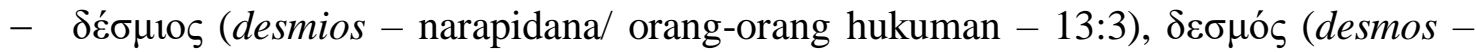

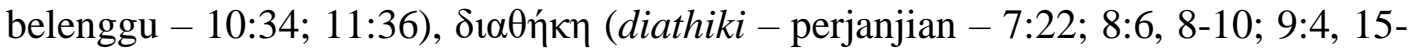

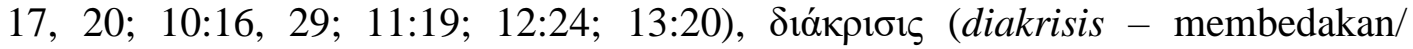
perkiraan yudisial - 5:14), díkaıs (dikeos - benar - 10:38, 11:4; 12:23),

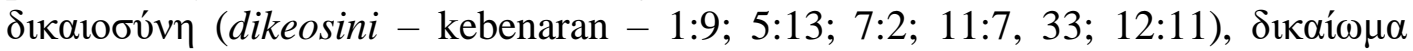
(dikeoma - peraturan - 9:1, 10).

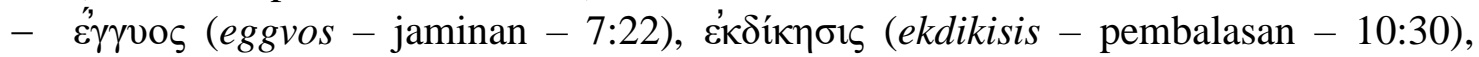

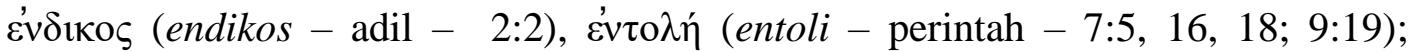

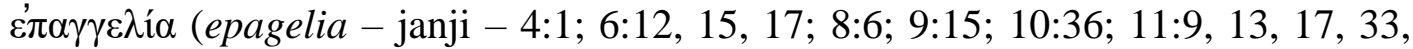
39).

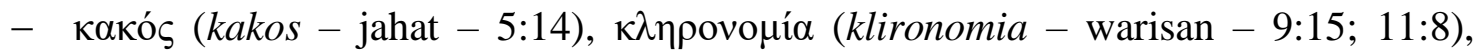

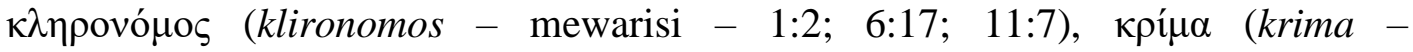

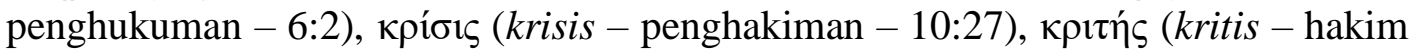
- 12:23), крıєєќ́ (kritikos - mampu membedakan/ menghakimi - 4:12).

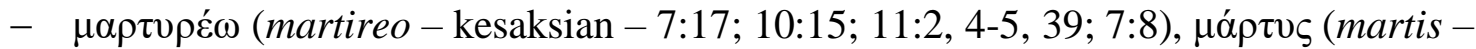

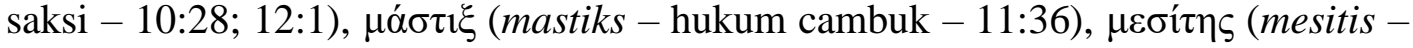
mediator/ pengantara $-8: 6 ; 9: 15 ; 12: 24)$.

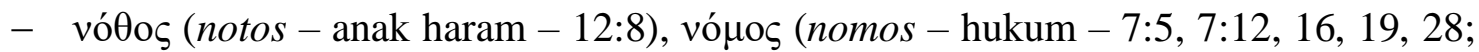
$8: 4,10 ; 9: 19,22 ; 10: 1,8,16,28)$.

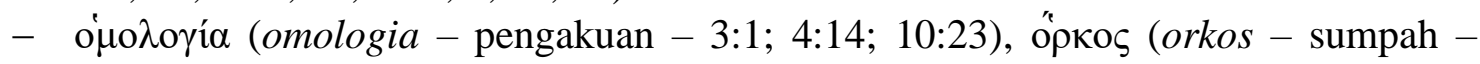

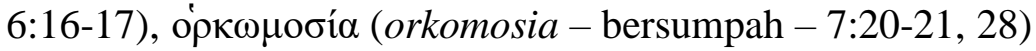

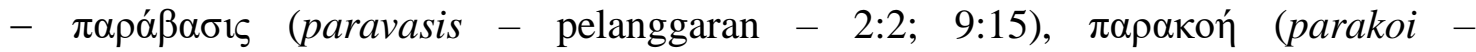

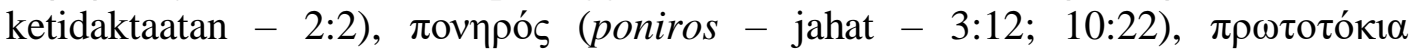

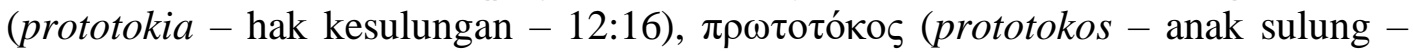
$1: 5-6 ; 11: 28 ; 12: 23)$.

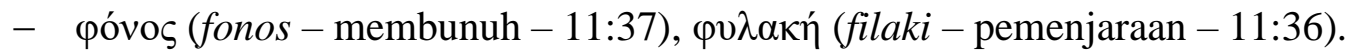

Banyaknya istilah hukum yang dipakai membuktikan bahwa penulis tertarik dengan bidang hukum.

\section{Penulis menggunakan banyak lambang/simbol/alegori dalam tulisannya}

Selain Tuhan Yesus yang kerap menggunakan alegori, ternyata penulis Ibrani juga beralegori dalam suratnya ini. Berikut contoh-contohnya:

- Allah dilambangkan sebagai ahli bangunan (3:4).

- Firman Allah digambarkan sebagai pedang yang kuat dan tajam (4:12).

- Pengajaran asas-asas pokok digambarkan sebagai susu dan dikontraskan dengan makanan keras (5:12-14).

- Situasi hati manusia dilambangkan dengan tanah yang menghisap hujan dan tanah yang menghasilkan semak duri (6:7-8).

- Pengharapan dilambangkan sebagai sauh yang kuat dan aman (6:19).

- Korban yang tak sempurna dikiaskan sebagai korban dalam ritus ibadah tabernakel Musa (9:1-9).

- Percikan darah sebagai lambang penyucian dosa (9:13-23).

- Perjanjian lama dilambangkan sebagai wasiat yang belum sah (9:16-18).

- Hukum Taurat sebagai bayangan dari keselamatan di masa depan (10:1).

- Sorga dilambangkan sebagai tanah air yang dinantikan (11:13-16). 
- Pahlawan-pahlawan iman digambarkan sebagai saksi yang mengelilingi bagaikan awan (12:1).

- Umat yang tidak dihajar dilambangkan sebagai anak haram (12:7-8).

- Kelemahan iman digambarkan sebagai tangan yang lemah, lutut yang goyah dan jalan yang pincang (12:12-13).

- Kepahitan dilambangkan sebagai akar yang menancap dalam (12:15).

- Allah digambarkan sebagai api yang menghanguskan (12:29).

- Penyaliban Yesus di luar tembok Yerusalem dilambangkan sebagai korban yang dibakar di luar perkemahan (13:11-12).

- Yesus disebut sebagai Gembala Agung segala domba (13:20).

Contoh-contoh tersebut membuktikan bahwa penulis Ibrani menggunakan banyak lambang/ simbol/ alegori dalam tulisannya.

\section{Penulis sering minta didoakan}

Dalam Ibrani 13:18 penulis memohon agar pembaca suratnya mendoakannya. Tampaknya ini adalah sesuatu yang kerap dimintanya, mengingat banyaknya penderitaan yang dihadapi oleh penulis. Argumentasi ini didukung dengan pernyataan selanjutnya dalam 13:19, penulis meminta agar hal itu (mendoakannya) dilakukan dengan lebih sering lagi ( $\pi \varepsilon \rho \iota \sigma \sigma o \tau \varepsilon ́ \rho \omega \varsigma$ - perissoteros).

\section{Penulis sedang dipenjara atau sedang sakit}

Dalam 13:18-19 penulis mohon didoakan agar ia lekas dikembalikan. Dalam bahasa aslinya $\alpha \dot{\pi} о \kappa \alpha \tau \alpha \sigma \tau \alpha \theta \tilde{\omega}$ (apokatastatho) artinya bisa disehatkan kembali, tapi bisa juga berarti dikembalikan ke rumah/ organisasi. Mengingat penulis beberapa kali menyinggung pembelengguan/ pemenjaraan $(10: 34 ; 11: 36 ; 13: 3)$ dan pembebasan Timotius (13:23), maka tampaknya istilah aposkatastatho menunjuk kepada pemenjaraan. Namun mengingat penulis juga kerap menyinggung tentang penderitaan, maka sakit karena penderitaan juga adalah sesuatu yang mungkin.

\begin{tabular}{|c|c|c|}
\hline Kategori Petunjuk & No & Bukti-bukti Internal \\
\hline \multirow{2}{*}{ Ciri Fisik } & 1 & Seorang laki-laki \\
\hline & 2 & Setidaknya berusia 50 tahun saat surat Ibrani ditulis \\
\hline \multirow{5}{*}{ Pendidikan } & 3 & Seorang yang terpelajar \\
\hline & 4 & Bisa berkomunikasi dalam beberapa bahasa \\
\hline & 5 & Berasal dari luar wilayah Israel/ Palestina \\
\hline & 6 & Pernah menimba ilmu di kota besar \\
\hline & 7 & Pernah belajar dari guru yang berkualitas \\
\hline \multirow{2}{*}{$\begin{array}{l}\text { Latar Belakang } \\
\text { Keluarga }\end{array}$} & 8 & Keturunan Yahudi \\
\hline & 9 & Berasal dari keluarga yang mapan \\
\hline \multirow{10}{*}{$\begin{array}{l}\text { Kehidupan Rohani dan } \\
\text { Pelayanan }\end{array}$} & 10 & Memiliki banyak kesamaan kepercayaan dengan Farisi \\
\hline & 11 & Seorang Kristen \\
\hline & 12 & Meninggalkan Yudaisme dan mengikut Yesus \\
\hline & 13 & Tidak melihat langsung hidup dan pelayanan Yesus \\
\hline & 14 & Pemimpin yang terpandang di gereja \\
\hline & 15 & Seorang penginjil/ pengajar keliling \\
\hline & 16 & Seorang penulis \\
\hline & 17 & Berafiliasi dalam sebuah komunitas penginjilan \\
\hline & 18 & Telah mengalami banyak sengsara dalam pelayanannya \\
\hline & 19 & Pernah mengalami realitas surgawi selama hidupnya \\
\hline \multirow{2}{*}{ Informasi Lain } & 20 & Mengenal Timotius \\
\hline & 21 & Memiliki ketertarikan kepada tenda \\
\hline
\end{tabular}




\begin{tabular}{|l|l|l|}
\hline \multirow{4}{*}{} & 22 & Menggunakan banyak istilah hukum \\
\cline { 2 - 3 } & 23 & Menggunakan banyak lambang/ simbol/ alegori dalam tulisannya \\
\cline { 2 - 3 } & 24 & Sering minta didoakan \\
\cline { 2 - 3 } & 25 & Sedang dipenjara atau sakit \\
\hline
\end{tabular}

\section{Kesesuaian Paulus dengan Bukti-bukti Internal}

Berikut pembuktian kesesuaian Paulus dengan bukti-bukti internal dalam surat Ibrani:

1. Paulus adalah seorang laki-laki

Ketika kemunculan namanya pertama sekali dalam PB, Lukas mendeskripsikannya

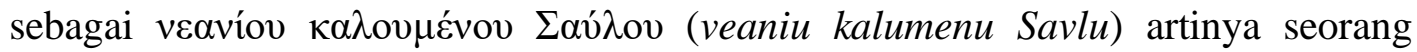
pemuda yang bernama Saulus (Kis. 7:58).

2. Paulus setidaknya berusia 50 tahun saat surat Ibrani ditulis.

Tahun kelahiran Paulus tidaklah pasti, namun rentang yang diberikan adalah 3-6M.

Maka pada tahun 64M, ia sudah melebihi usia 50 tahun.

3. Paulus adalah seorang yang terpelajar

Kemampuan bahasa Yunani Paulus ditambah bahwa ia adalah murid Gamaliel (Kis.

22:3) menunjukkan bahwa Paulus seorang terpelajar

4. Paulus bisa berkomunikasi dalam beberapa bahasa

- Paulus bisa berbahasa Aram/ Ibrani. Di jalan menuju Damaskus, Allah berbicara kepadanya dalam bahasa Ibrani (Kis. 26:14). Ia juga dididik tentang hukum Taurat oleh rabi Gamaliel (Kis. 22:3).

- Ia juga bisa bahasa Yunani, sebab surat-suratnya ditulis dalam bahasa Yunani. Ia menginjil kepada orang-orang Athena di atas Areopagus (Kis. 17:22-32) tentunya juga dalam bahasa Yunani. Ia pernah juga tinggal di tanah Yunani selama tiga bulan (Kis. 20:2-3).

- Paulus bisa bahasa Latin. Beberapa kali dicatat ia berhubungan dengan orangorang di Italia (Kis. 28:30), tentara Roma (Kis. 28:16), perwira Roma (Kis. 27:1), dan pejabat-pejabat Romawi lainnya yang dalam komunikasi sehari-hari diharuskan berbicara dalam bahasa Latin. ${ }^{27}$

5. Paulus berasal dari luar wilayah Israel/ Palestina

Ia lahir di Tarsus, sebuah kota di Kilikia (Kis. 9:11; 22:3).

6. Paulus pernah menimba ilmu di kota besar

Paulus setidaknya pernah belajar di dua kota besar. Pertama, Tarsus ketika ia masih muda, dan kedua, di Yerusalem, di bawah bimbingan rabi Gamaliel (Kis. 22:3).

7. Paulus pernah belajar dari guru yang berkualitas

Paulus mengatakan bahwa ia adalah murid Gamaliel (Kis. 22:3). Dalam tradisi

Kristen, Gamaliel dianggap sebagai doktor Farisi dalam bidang hukum Taurat.

8. Paulus adalah keturunan Yahudi

Dalam Kisah Para Rasul 22:3, dengan jelas ia menyebut dirinya sebagai orang Yahudi. Ia berasal dari suku Benyamin (Rm. 11:1; Flp. 3:4-5).

9. Paulus berasal dari keluarga yang mapan

Fakta bahwa keluarganya mampu mengirimnya untuk belajar di bawah asuhan rabi Gamaliel (Kis. 22:3) dan kewarganegaraan Roma yang dimiliki oleh Paulus (Kis. 16:37; 22:25; 25:11), menunjukkan bahwa keluarga Paulus cukup mapan.

10. Paulus memiliki banyak kesamaan kepercayaan dengan Farisi

Paulus percaya akan kebangkitan (Kis. 17:18, 31; 23:6; 24:15; Rm. 6:5; 8:11; 1Kor. 15:12-17, 21; Flm. 3:11), malaikat (Kis. 27:23; Rm. 8:38; 1Kor. 4:9; 6:3; Gal. 3:19; Kol. 2:18; 2Tes. 1:7; 1Tim. 3:16; 5:21), makhluk roh (Kis. 16:18; 19:11-16; Rm.

\footnotetext{
${ }^{27}$ Barclay, PASH Filipi, 51.
} 
8:38; Ef. 1:21; 2:2; 3:10; 6:12; Kol. 1:16), kekekalan jiwa manusia (Rm. 2:7; 1Kor. 15:53, 54; 2Tim. 1:10), penghakiman (Kis. 17:31; Rm. 2:3, 5-6; 14:10; 2Kor. 5:10; 2Tim. 4:1), ganjaran setelah kematian (Rm. 2:6; 2Kor. 5:10; 2Tim. 4:8). Tapi, tidak seperti orang Farisi yang menekankan sunat lahiriah (Kis. 15:1-2; Rm. 4:11), ia justru menekankan sunat batiniah (Rm. 2:28-29; Kol. 2.11). Farisi menekankan keselamatan di bawah ketaatan terhadap hukum Musa (Kis. 15:5), sebaliknya Paulus menekankan kasih karunia Allah (Kis. 13:39; Rm. 6:14; Gal. 2:16; 5:4; Ef. 2:8-9).

11. Paulus adalah seorang Kristen

Paulus sendiri mengklaim dirinya sebagai orang Kristen (Kis. 11:25-26; 26:28; Rm. 16:7; 1Kor. 9:5; 2Kor. 12:2)

12. Meninggalkan Yudaisme dan mengikut Yesus

Dia disunat pada hari kedelapan, bangsa Israel, suku Benyamin, Ibrani asli, orang Farisi, tak bercacat dalam hukum Taurat (Flp. 3:5), tapi karena pengenalan akan Yesus, dia kemudian menganggap Yudaismenya sebagai kerugian dan sampah belaka (Flp. 3:7-8).

13. Paulus tidak melihat langsung hidup dan pelayanan Yesus

Ia baru muncul saat pembunuhan Stefanus (Kis. 7:58). Perjumpaannya dengan Yesus di jalan menuju Damaskus menunjukkan ia tidak pernah berjumpa ataupun mengenal Yesus sebelumnya (Kis. 9:3-5; 22:6-8)

14. Paulus adalah pemimpin yang terpandang di gereja Ia adalah seorang rasul (Rm. 1:1; 1Kor. 1:1; 2Kor. 1:1; Gal. 1:1; Ef. 1:1; Kol. 1:1; 1Tim. 1:1; 2:7; 2Tim. 1:1; Tit. 1:1) bagi bangsa-bangsa non Yahudi (Gal. 2:9).

15. Paulus adalah penginjil/ pengajar keliling Lukas mencatat tiga perjalanan misi Paulus mengabarkan Injil, mengajar, dan menguatkan hati jemaat (Kis. 13:1-27; 15:36-18:22; 18:23-21:19).

16. Paulus adalah seorang penulis

Di luar surat Ibrani yang diperdebatkan, dia adalah penulis 13 surat yang masuk ke dalam kanon PB (Roma, 1\&2 Korintus, Galatia, Efesus, Filipi, Kolose, 1\&2 Tesalonika, $1 \& 2$ Timotius, Titus, Filemon).

17. Paulus berafiliasi dalam sebuah komunitas penginjilan

Dalam perjalanan misinya, Paulus sudah bekerja sama dengan begitu banyak orang, yang nama-namanya disebutkan dalam surat-suratnya dan dalam catatan Lukas (Kis. 15:40; 16:14; 17:34; 18:8; 19:9, 33; 20:4; Rm. 16:1-23; 1Kor. 1:1; 16:12, 17; Ef. 6:21-22; Flp. 2:25; Kol. 4:7-17; 1Tes. 1:1; 2Tim. 4:9-21; Tit. 1:5; 3:12-13; Flm. 22-24).

18. Paulus telah mengalami banyak sengsara dalam pelayanannya

Dalam perjalanan misinya, Paulus telah berkali-kali disesah, dilempari batu, dan dipenjara (Kis. 14:19; 16:23; 21:30-33; 22:25; 23:35; 24:23, 27; 27:1; 28:16, 30). Dalam suratnya kepada jemaat Korintus, ia juga menceritakan penderitaannya (1Kor. 4:11-13; 2Kor. 4:8-11; 6:8-10; 11:23-27).

19. Paulus pernah mengalami realitas surgawi selama hidupnya Paulus dengan jelas memberikan kesaksian tentang hal ini dalam suratnya kepada jemaat di Korintus (2Kor. 12:2-4). Ia menceritakan bagaimana ia diangkat ke tingkat yang ketiga dari surga, dan ia mendengar kata-kata yang tak terkatakan, yang tidak boleh diucapkan manusia. Ini merupakan sebuah fakta tak terbantahkan bahwa Paulus memang benar-benar pernah mengalami realitas surgawi.

20. Paulus mengenal Timotius 
Timotius kemungkinan besar adalah murid hasil penginjilan Paulus dan Barnabas di Listra dan Derbe dalam perjalanan misi Paulus yang pertama (Kis. 21 bd 16:1-2). Dalam pertemuan selanjutnya, Paulus menginginkan Timotius untuk menemaninya dalam perjalanan misinya (Kis. 16:3), dan selanjutnya Timotius menjadi mitra kerja dan anak rohani (1Tim. 1:2).

21. Paulus memiliki ketertarikan kepada tenda Dalam perjalanan pemberitaan Injilnya, ketika ia tidak dibiayai oleh siapapun, Paulus bekerja membuat tenda (Kis. 18:2-3 bd 1Kor. 9:6)

22. Paulus menggunakan banyak istilah hukum

Dalam surat-suratnya Paulus menggunakan banyak sekali istilah hukum, seperti:

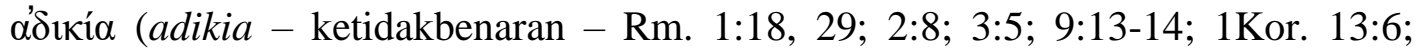

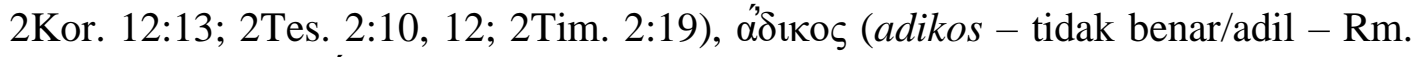

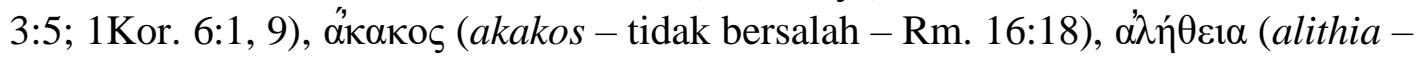
kebenaran - Rm. 1:18, 25; 2:2, 8, 20; 3:7; 9:1; 15:8; 1Kor. 5:8; 13:6; 2Kor. 4:2; 6:7; 7:14; 11:10; 12:6; 13:8; Gal. 2:5, 14; 3:1; 5:7; Ef. 1:13; 4:21, 24; 2Tes. 2:10, 12-13; 1Tim. 2:4, 7; 3:15; 4:3; 6:5; 2Tim. 2:15, 18, 25; 3:7-8; 4:4; Tit. 1:1, 14),

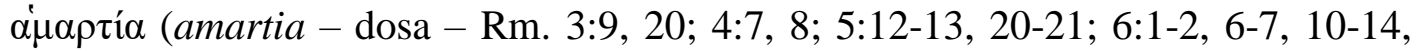
16-18, 20, 22-23; 7:5, 7-9, 11, 13-14, 17, 20, 23, 25; 8:2-3, 10; 11:27 14:23; 1Kor. 15:3, 17, 56; 2Kor. 5:21; 11:7; Gal. 1:4; 2:17; 3:22; Ef. 2:1; Kol. 1:14; 2:11; 1Tes.

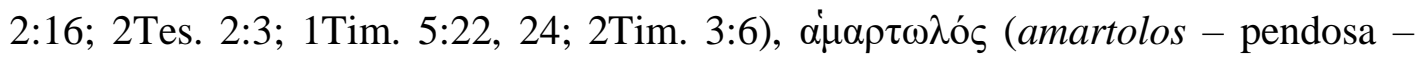

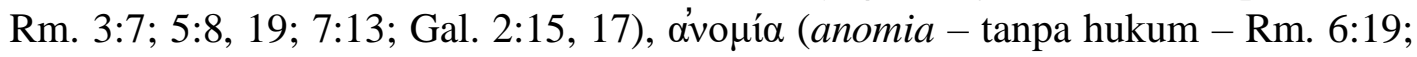

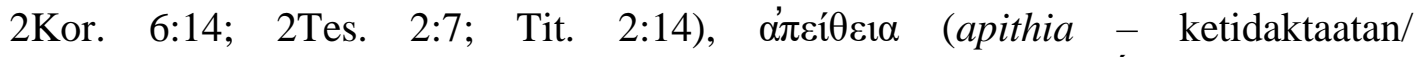

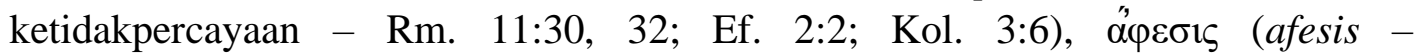
pengampunan - Ef. 1:7; Kol.1:14), $\beta \tilde{\eta \mu} \alpha$ (vima - kursi pengadilan - Rm. 14:10;

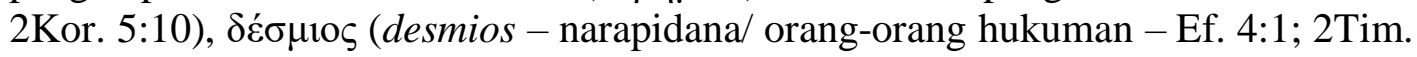

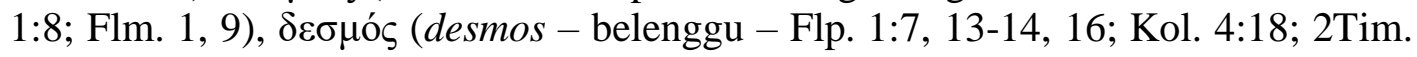

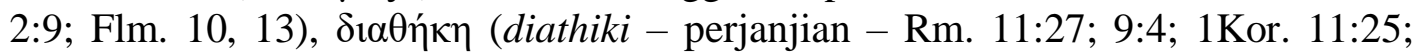

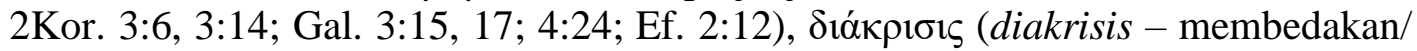
perkiraan yudisial - Rm. 14:1; 1Kor. 12:10), díkalos (dikeos - benar - Rm. 1:17; 2:13; 3:10, 26; 5:7, 19; 7:12; Gal. 3:11; Ef. 6:1; Flp. 1:7; 4:8; Kol. 4:1; 2Tes. 1:5-6;

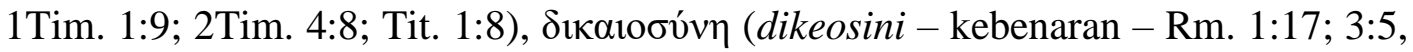
21-22, 25-26; 4:3, 5-6, 9, 11, 13, 22; 5:17, 21; 6:13, 16, 18-20; 8:10; 9:28, 30-31; $10: 3-6,10$; 14:17; 1Kor. 1:30; 2Kor. 3:9; 5:21; 6:7, 14; 9:9-10; 11:15; Gal. 2:21; $3: 6,21 ; 5: 5$; Ef. 4:24; 5:9; 6:14; Flp. 1:11; 3:6, 9; 1Tim. 6:11; 2Tim. 2:22; 3:16;

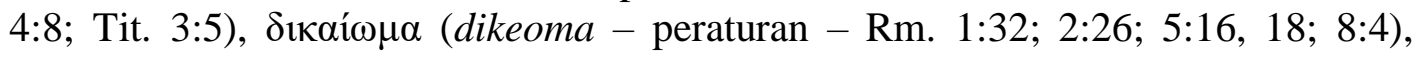

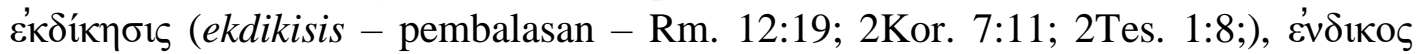

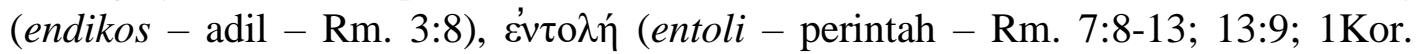

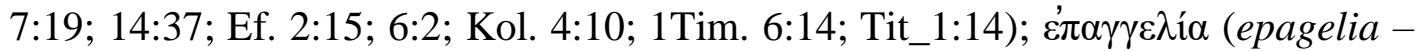
janji - Rm. 4:13-14, 16, 20; 9:4, 8-9; 15:8; 2Kor. 1:20; 2Kor. 7:1; Gal. 3:14, 16-18, 21-22, 29; 4:23, 28; Ef. 1:13; 2:12; 3:6; 6:2; 1Tim. 4:8; 2Tim. 1:1), кakó (kakos jahat - Rm. 1:30; 2:9; 3:8; 7:19, 21; 9:11; 12:17, 21; 13:3-4, 10; 14:20; 16:19; 1Kor. 10:6; 13:5; 15:33; 2Kor. 13:7; 5:10; Flp. 3:2; Kol. 3:5; 1Tes. 5:15; 1 Tim.

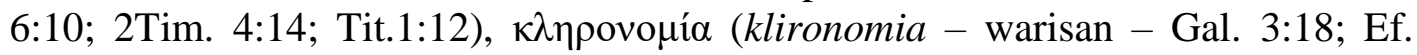

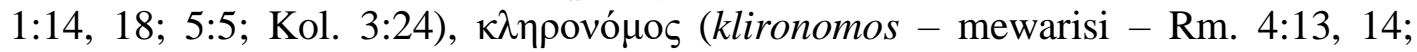
8:17; Gal. 3:29; 4:1, 4:7; Tit. 3:7), крí $\alpha$ (krima - penghukuman - Rm. 2:2-3; 3:8; 5:16; 11:33; 13:2; 1Kor. 6:7; 11:29, 34; Gal. 5:10; 1Tim. 3:6; 5:12), крíбı (krisis penghakiman - 2Tes. 1:5; 1Tim. 5:24), крıи́s (kritis - hakim - 2Tim. 4:8),

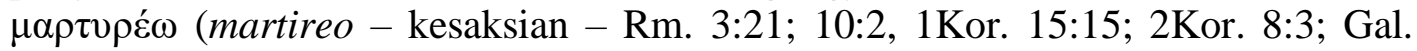

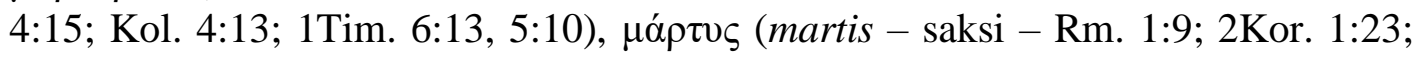




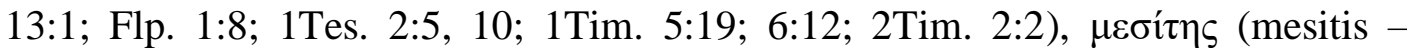
mediator/ pengantara - Gal. 3:19-20; 1Tim. 2:5), vó $3: 21$, 27-28, 31; 4:13-16; 5:13, 20; 6:14-15; 8:4, 7; 9:31-32; 10:4-5; 13:8, 10; 1Kor. 7:39; 9:8-9; 14:20-21, 34; 15:56; Gal. 2:16, 19, 21; 3:15; 4:5, 21; 5:3-4, 5:14, 18,

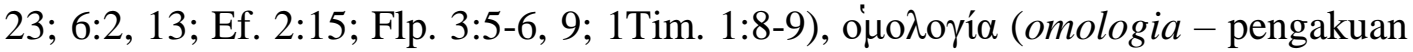

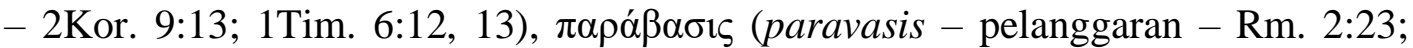
4:15; 5:14; Gal. 3:19; 1Tim. 2:14), таракой (parakoi - ketidaktaatan - Rm. 5:19;

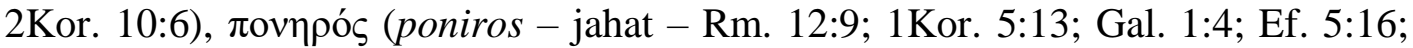
6:13, 16; Kol. 1:21; 1Tes. 5:22; 2Tes. 3:2, 3; 1Tim. 6:4; 2Tim. 3:13; 4:18), 甲óvo

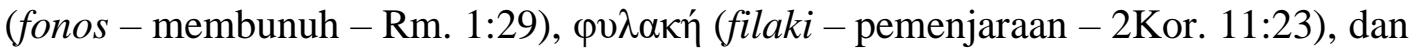
banyak lagi istilah hukum lainnya.

23. Paulus menggunakan banyak lambang/ simbol/ alegori dalam tulisannya

Dalam surat-surat Paulus, banyak diberikan perlambangan-perlambangan. Berikut beberapa contohnya: perbandingan Adam dengan Kristus (Rm. 5:12-21), baptisan sebagai gambaran penyatuan dengan kematian, penguburan dan kebangkitan Kristus (Rm. 6:6), tunas liar yang dicangkokkan kepada pohon zaitun (Rm. 11:1724), analogi tubuh dengan banyak anggota (Rm. 12:4-8; 1Kor. 12:12), Yesus Kristus sebagai perlengkapan senjata terang (Rm. 13:14), Paulus menafsirkan halhal yang rohani (1Kor. 2:13), susu dan makanan keras (1Kor. 3:2), Paulus menanam Apolos menyiram (1Kor. 3:6), ladang Allah, bangunan Allah (1Kor. 3:9), membangun dengan emas, perak, batu permata, kayu, rumput kering atau jerami (1Kor. 3:12), pendayung kapal Allah (1Kor. 4:1), penjaga rumah Allah (1Kor. 4:2), ragi yang lama, domba Paskah, roti yang tidak beragi (1Kor. 5:7-8), gelanggang pertandingan, pertandingan, mahkota, petinju (1Kor. 9:24-26), dibaptis dalam awan dan dalam laut (1Kor. 10:2), makanan rohani, minuman rohani, batu karang rohani (1Kor. 10:3-4), roti dan anggur sebagai tubuh dan darah Kristus (1Kor. 11:23-26), gong yang berkumandang dan canang yang gemerincing (1Kor. 13:1), Adam yang akhir (1Kor. 15:45), loh-loh daging (2Kor. 3:3), harta dalam bejana tanah liat (2Kor. 4:7), tubuh digambarkan sebagai kemah (2Kor. 5:1-4), duri dalam daging (2Kor. 12:7), Sara dan Hagai sebagai dua ketentuan Allah (Gal. 4:24-26), suami istri sebagai gambaran hubungan Kristus dengan jemaat (Ef. 5:32), perlengkapan senjata Allah (Ef. 6:11-18), dan banyak lagi perlambangan lainnya.

24. Paulus sering minta didoakan

Paulus adalah satu-satunya penulis PB yang memohon doa dari jemaat dalam surat yang ditulisnya. Paulus memohon agar mereka mendoakannya maupun mendoakan kelompok penginjilannya (Rm. 15:30; Ef. 6:18-20; Kol. 4:3; 1Tes. 5:25; 2Tes. 3:1; Flm. 22).

25. Paulus sedang dipenjarakan atau sakit

Lukas mencatat pemenjaraan Paulus yang pertama di Roma (Kis. 28:30) selama dua tahun penuh (61-63M). ${ }^{28}$ Selanjutnya ia dibebaskan untuk waktu yang sebentar, ${ }^{29}$ sehingga ia sempat mengadakan perjalanan ke Efesus (1Tim. 1:3; 3:1415), Makedonia (1Tim. 1:3), mungkin ke Spanyol (Rm. 15:24-28), Korintus (2Tim. 4:20), Troas (2Tim. 4: 13) dan Nikopolis (Tit. 3:12). Setelah itu ia ditangkap dan dipenjarakan kembali (2Tim. 1:8, 16-17) di Roma, sebelum dieksekusi mati oleh

\footnotetext{
${ }^{28}$ G. Tulus Sudarto, Life Begins at 24 Inspirasi Paulus Untuk Kaum Muda, (Yogyakarta: Penerbit Kanisius, 2009), 18; Enns, Op. Cit., 124.

${ }^{29}$ Pamphilus, Op. Cit., 2.22.
} 
Nero tahun 67/68M. ${ }^{30}$ Mengingat 2 Timotius ditulis tahun $65 \mathrm{M},{ }^{31}$ maka bisa disimpulkan bahwa Paulus sudah berada di penjara Roma untuk kedua kalinya tahun 64M/65M sampai dihukum mati dengan dipenggal tahun 67M/68M. Sakit juga adalah sesuatu yang kerap dialami (Gal. 4:13; 6:11).

\section{KESIMPULAN}

Setelah dilakukan penelitian yang cermat terhadap teks surat Ibrani, maka ditemukan 25 bukti internal penulis surat Ibrani. Ketika semua data tersebut dibandingkan dengan profil rasul Paulus, maka Paulus cocok dengan semua bukti internal surat Ibrani. Ini membuktikan bahwa rasul Paulus adalah penulis surat Ibrani.

\section{REFERENSI}

Alkitab, Jakarta: Lembaga Alkitab Indonesia.

Adam J. Wesley, Alkitab Penuntun Hidup Berkelimpahan, Malang: Penerbit Gandum Mas \& Jakarta: LAI, 2006.

Allen David Lewis, Lukan Authorship of Hebrews, Nashville, Tennessee: B\&H Publishing Group, 2010.

Attridge Harold W., The Epistle to the Hebrews: A Commentary on the Epistle to the Hebrews. Ed. Helmut Koester, Philadelphia: Fortress, 1989.

Barclay William, Pemahaman Alkitab Setiap Hari - Surat Filipi, Kolose, 1 dan 2 Tesalonika, Jakarta: PT. BPK Gunung Mulia, 2004.

Pemahaman Alkitab Setiap Hari - Surat Ibrani, Jakarta: PT. BPK Gunung Mulia, 2006.

Brown Raymond E., An Introduction to the New Testament, New York: Doubleday, 1997.

Bruce F. F., The Epistle to the Hebrews - Revised Edition, Michigan: William B. Eerdmans Publising Company, 1990.

Cartledge Samuel A., A Conservative Introduction to the New Testament. 2nd ed, Grand Rapids: Zondervan, 1938.

Drane John, Memahami Perjanjian Baru - Pengantar Historis - Teologi, Jakarta: PT. BPK Gunung Mulia, 2013.

Ellingworth Paul, The Epistle to the Hebrews: A Commentary on the Greek Text, Grand Rapids: Wm. B. Eerdmans Publishing, 1993.

Eusebius Pamphilus, Historia Ecclesiae, 6.25.6.

Gilbert Rose, Plato's Apology: Commentary, Bryn Mawr: Thomas Library, Bryn Mawr College, 1989.

Guthrie Donald, New Testament Introduction 4th ed, Leicester: Apollos; Downers Grove: Inter-Varsity, 1990.

Hakh Samuel Benyamin, Perjanjian Baru - Sejarah, Pengantar, dan Pokok-pokok Teologinya, Bandung: Bina Media Informasi, 2010.

Hughes Philip Edgcumbe, A Commentary on the Epistle to the Hebrews, Grand Rapids: Eerdmans, 1977.

Lenski Richard C. H., Commentary on the New Testament: The Interpretation of the Epistle to the Hebrews and of the Epistle of James, Peabody: Hendrickson, 1966.

\footnotetext{
${ }^{30}$ Bill Jones, Putting Together the Puzzle of the New Testament, (Columbia: Crossover Communications International, 2009), 203-204; John D. Rouse, Paul the Passionate Scholar, (Bloomington, USA: WestBow Press, 2014), 399; John B. Polhill, Paul and His Letters, (Nashville, Tennessee: Broadman \& Holman Publisher, 1999), 439; Lawrence Boadt, The Life of St. Paul, (New Jersey: Paulist Press, 2008), 92; Paul Enns, Op. Cit., 124.

${ }^{31}$ R. Budiman, Tafsiran Alkitab Surat-surat Pastoral I\&II Timotius Dan Titus, (Jakarta: PT. BPK Gunung Mulia, 2008), 75;
} 
Lindars Barnabas, The Theology of The Letter to The Hebrews, Cambridge: Cambridge University Press, 1991.

Marxsen Willi, Pengantar Perjanjian Baru - Pendekatan Kritis Terhadap Masalahmasalahnya, Jakarta: PT BPK Gunung Mulia, 2014.

McGee J. Vernon, "The Epistle to the Hebrews" Thru the Bible with Vernon McGee, Vol. 5, Nashville: Nelson, 1983.

Plato, The Apology of Socrates - Selections from Plato with Introduction and Notes. Ed. Lewis Learning Forman, London: Macmillan, 1939.

Plutarch, Demosthenes - The Lives of the Noble Grecians and Romans - Great Books of the Western World - Ed. Robert Maynard Hutchins, Vol.14, Chicago: Britannica, 1952.

Ross Robert W., The Wycliffe Bible Commentary-Ibrani, Volume 3, Malang: Penerbit Gandum Mas, 2008.

Tenney Merrill C., Survei Perjanjian Baru, Malang: Penerbit Gandum Mas, 2009.

Thiele Richard A., A Reexamination of the Authorship of the "Epistle to the Hebrews", (Milwaukee, USA: University of Wisconsin - ProQuest Dissertations Publishing, 2008.

Utley Bob, Keunggulan Perjanjian Baru: Ibrani - Kumpulan Komentari Panduan Belajar Perjanjian Baru, Vol. 10, Texas: Bible Lesson International, 1999.

Wahono S. Wismoady, Di Sini Kutemukan, Jakarta: PT. BPK Gunung Mulia, 2009. 